\title{
A STUDY OF GAMMA GLOBULIN IN RHEUMATOID ARTHRITIS ${ }^{1}$
}

\author{
By J. H. VAUGHAN,2 A. ARMATO, J. C. GOLDTHWAIT, P. BRACHMAN, \\ C. B. FAVOUR, AND T. B. BAYLES \\ (From the Medical Services of the Peter Bent Brigham and Robert Breck Brigham Hospitals, \\ and the Department of Medicine, Harvard Medical School, Boston, Mass.)
}

(Submitted for publication April 9, 1954 ; accepted August 20, 1954)

For a number of years the attention of many investigators of rheumatoid arthritis has centered on the abnormality of the serum proteins in this disease, clinically manifested by a high globulin. Changes in the electrophoretically determined serum globulins have been reported (1), and to them the unusual agglutinating and precipitating properties of rheumatoid sera have been attributed (2-6). Recently evolved techniques for the isolation of plasma proteins by precipitation in cold alcohol $(7,8)$ and the current availability of radioisotopes for labelling purposes $(9,10)$ have provided another method for studying the fate of plasma proteins in blood and tissues.

A study of gamma globulin in patients with rheumatoid arthritis by means of these newer techniques is the subject of the present report.

1. Groups of patients with rheumatoid arthritis and groups of normal controls were given intravenous injections of $\mathrm{I}^{181}$-tagged Fraction II (gamma globulin) and similarly tagged Fraction $\mathrm{V}$ (albumin). The rate of disappearance of these two proteins from the blood during the first two weeks was determined from the radioactivity remaining in serial plasma samples.

2. The in vitro adsorption by defatted joint tissue stromata of I $^{131}$-tagged samples of rheumatoid and control plasma Fraction II was studied.

3. Tagged Fractions II and V were given intravenously in different experiments to rheumatoid and non-rheumatoid subjects just before orthopedic operations. The uptake of radioactivity was measured in specimens of joint tissues removed during the operative procedure.

\section{MATERIALS AND METHODS}

Plasma fractionation. Plasma fractions were prepared by a modification (7) of Cohn's cold alcohol precipita-

1 This work was supported by U. S. Public Health Service Grants RG2689 and A-34 (C) and the Nell Lucas Forsythe Fund of the Harvard Medical School.

2 Present address: Medical College of Virginia, Richmond, Virginia. tion technique (Method No. 10) (8). The fractionation was further modified in this laboratory to facilitate radioactive tagging of the isolated proteins. The collection of fractions on glass filters by means of suction was replaced by sedimentation of precipitates in a refrigerated centrifuge; in the latter part of the fractionation procedure protein pastes were taken up in $0.04 \mathrm{M}$ instead of $0.15 \mathrm{M}$ saline, so that the anion exchange resin used subsequently to remove excess $I^{13}$ and its carrier would not become saturated with chloride. Fraction II, consisting primarily of gamma globulin, was prepared from plasma pools derived from normal individuals as well as from separate pools derived from patients with rheumatoid arthritis. Fraction V, albumin, was obtained from a commercial source. ${ }^{8}$

Iodination. Iodination was accomplished by equilibrating the protein solutions against $I^{m}$ in a carrier of iodine and potassium iodide. The technique was a modification of the methods used by Latta (9) and by Pressman (10). Since the iodine is taken up by the tyrosine molecules in protein the first step in determining the amount of carrier to be used was a Folin-Ciocalteu tyrosine analysis (11) of the protein solution. The assumption was then made that for gamma globulin 60 moles of tyrosine were contained in one mole of protein and for albumin 20 moles of tyrosine per mole of protein (12). Preliminary experiments revealed that satisfactory iodination could be accomplished by using a ratio of 6 moles of $I_{2}$ to one mole of protein. Uptake of radioactivity by the protein when these proportions were used varied from 20 to 40 per cent. Thus, since the carrier solution contained $5 \times 10^{-6} \mathrm{mg}$. of $\mathrm{I}_{2}$ per ml., the amount of carrier to be used could be calculated. One millicurie of $I^{121}$ was added to the appropriate volume of carrier and this, following adjustment of $\mathrm{pH}$ to $8.5-9.0$ by means of a glycine buffer, was added to the protein solution. Uncombined iodine was removed by dialysis against a glycine-buffered ( $\mathrm{pH} 8.5$ - 9.0) $0.04 \mathrm{M}$ saline solution containing an anion exchange resin IRA-400. At the end of the dialysis unbound radioactivity in the protein solution was found to be less than 1 per cent.

Determination of radioactivity. Counts of radio-activity were made with an end-window Geiger-Muller tube and a Tracerlab autoscaler. Duplicate ml. samples were pipetted into planchettes and allowed to air dry. Cracking occurred occasionally but was not sufficiently common to prove a hindrance. No correction was made for absorption, since in each section of the work pro-

${ }^{8}$ Cutter Laboratories, Berkeley, California.

4 Rohm and Haas Co., Philadelphia, Pennsylvania. 
tein concentrations were approximately the same and this value was considered to be constant.

Adsorption of isoagglutinins. Traces of isoagglutinins were adsorbed from pooled Fraction II by three successive equilibrations at room temperature of given volumes of protein solution with equal volumes of thoroughly washed (eight times) human type $A B, R h$ positive, erythrocytes.

Preparation of tissue for in vitro adsorption studies. Synovial and adjacent joint capsule biopsies ${ }^{b}$ obtained during the course of surgical procedures were placed in stoppered containers, frozen by immersing the containers in a mixture of solid $\mathrm{CO}_{2}$ and 95 per cent ethanol, and stored at $-20^{\circ} \mathrm{C}$. Stromata were prepared by thawing the material, mincing it in saline at 0 to $4^{\circ} \mathrm{C}$, grinding it in a tissue grinder, ${ }^{\circ}$ washing the fragments by centrifugation from saline, and lyophilizing the sediment. The dried material was pulverized and extracted twice with cold ether. The resulting removal of fat provided a tissue preparation composed of evenly divided particles which could be readily suspended in saline.

Measurement of in vitro tissue uptake of globulin. For uptake studies $1.5 \mathrm{ml}$. aliquots of the iodinated plasma fractions were mixed with equal volumes of 2 per cent suspensions of the tissue particles, incubated for 40 to 60 minutes at $37^{\circ} \mathrm{C}$., and washed by centrifugation from saline. The tissues were resuspended in $3 \mathrm{ml}$. volumes. Counts were made on duplicate $1 \mathrm{ml}$. aliquots of these tissue suspensions, on the supernates of the last washings, and on aliquots of the original tagged fraction. The radioactivity in the last washings were in all instances at, or nearly at, background.

Measurement of in vivo tissue uptake of globulin. Biopsy specimens from patients who had received a tagged plasma fraction preceding surgery were washed free of blood with saline before further study. In the initial experiments radioactivity was expressed as counts per gram of tissue before and after desiccation. In subsequent experiments radioactivity was expressed as counts per $10 \mathrm{mg}$. of tissue nitrogen as well. Samples were weighed wet and then digested in a mixture of concentrated nitric acid, 30 per cent hydrogen peroxide and silver nitrate in a water bath at $80^{\circ} \mathrm{C}$. (13). In this process the iodine was precipitated by silver nitrate and the precipitate was collected by filtration. The section of filter paper holding the precipitate was placed in a planchette and counted in the usual manner. Nitrogen assays on the filtrate were determined with Nessler's solution. The results were recorded as counts per 10 mg. of nitrogen. This value was compared with the number of counts per $\mathrm{ml}$. of plasma obtained at the same time that the biopsy was taken. It was assumed that the

- We are indebted to Doctors John G. Kuhns, Theodore A. Potter, Robert S. Hormell, George Van Gorder, Thomas B. Quigley, Henry Banks, and Joseph Fleming, whose interest and cooperation made possible the procurement of the tissue specimens.

- Ten Broeck grinder. Scientific Glass Apparatus Co., Bloomfield, New Jersey. plasma total nitrogen did not vary significantly from the value of $10 \mathrm{mg}$. per $\mathrm{ml}$.

\section{RESULTS}

\section{Part I. Disappearance of tagged fractions}

The disappearance of intravenously injected Fraction II was studied in eight experiments. In four of these, gamma globulin was obtained from pooled plasma samples of normal individuals; in the other four the gamma globulin came from patients with active rheumatoid arthritis. Healthy young hospital personnel were used as normal subjects; the rheumatoid arthritis patients were somewhat older and were all hospitalized with moderate to severe disease. From six to ten individuals were represented in each plasma pool studied. In each experiment there were eight recipients: Four patients with rheumatoid arthritis and four normal controls. Recipients were given Lugol's solution daily to prevent localization of $\mathrm{I}^{181}$ in the thyroid.

The data describing the disappearance of radioactivity from the circulating blood are presented in Figures 1, 2, and 3. A semi-logarithmic plot of the plasma count, expressed as per cent of initial (generally thirty-minute) count, was made against time. It is evident in Experiments II, III, IV, and $\mathrm{V}$ (Figure 1) that there was a more rapid loss of the radioactive material from the blood of the rheumatoid arthritis patients than there was from that of the normal persons. Neither patients nor control recipients, however, differentiated between normal and rheumatoid plasma protein fractions. In Experiments II, IV, and V, the average tagged-protein half-life in the normal persons was found to be $7.7,8.3$, and 7.2 days, respectively, while the same averages for the rheumatoid arthritis group appeared to be one to two days shorter. The values obtained on the fourth and eleventh post-injection days in Experiments II through V, when subjected to statistical analysis, gave a probability value of 0.01 . It was difficult to form a valid estimate of the half-life of the materials injected into the rheumatoid subjects, as plots of the data did not form straight lines after the second day.

In Experiment III the disappearance of radioactive material in both patients and controls was more rapid than in the previous experiments. 

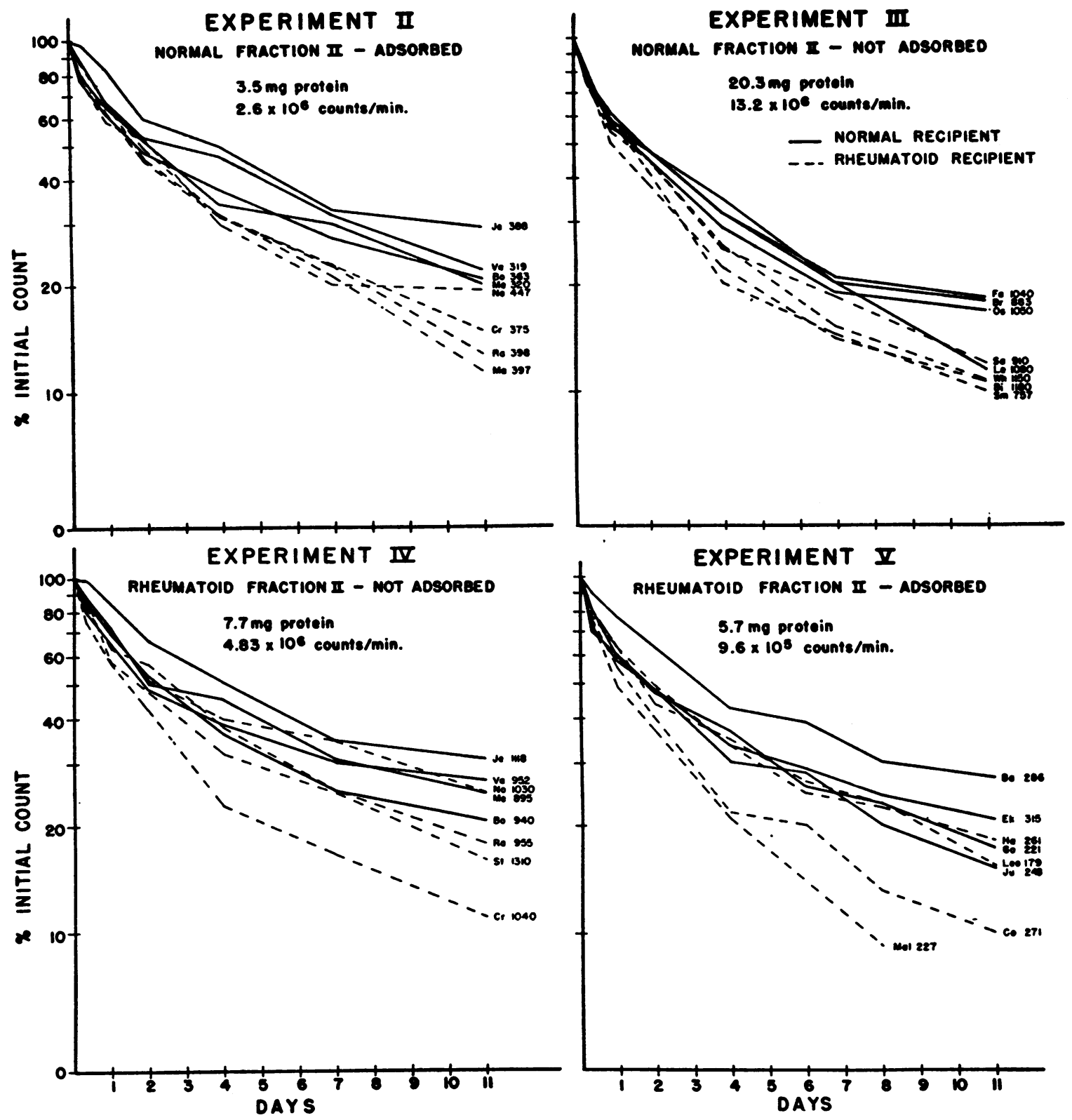

Fig. 1. Experiments II-V, Illustrating the More Rapid Disappearance of Radioactive Material froy the Blood of Rheumatom Individuals as Compared to Normals

The numbers accompanying each line refer to the counts per minute per milliliter of the initial (30-minute) plasma sample.

Gamma globulin used in this experiment was provided by Dr. J. L. Oncley of the Department of Physical Chemistry at Harvard Medical School; in the other experiments the Fraction II was prepared by the authors as described above. The test subjects of Experiment III were injected with aliquots of the material which had been tagged in the usual manner. The remainder was dialyzed against a Veronal buffer at $\mu=0.1 \mathrm{M}$ and $\mathrm{pH} 8.6$ in preparation for re-examination by electrophoresis. During dialysis an insoluble precipitate formed. Electrophoretic analysis of the protein remaining in solution indicated that it was unchanged gamma globulin. This supernate contained approximately half the original radioactivity. An aliquot of this soluble dialyzed Frac- 
tion II was injected into a single normal subject and its disappearance followed. A half-life of 6.2 days was found in this experiment, a value quite close to that of 6.0 , the average half-life found for the original material. It is to be noted that the latter figure is an approximation, since the disap- pearance curve shown in Figure 1, Experiment II, nowhere becomes a straight line.

Figure 2 gives a graph of the results of Experiments I and VI, where it was observed that there was strikingly less activity in the initial samples from the rheumatoid patients than there
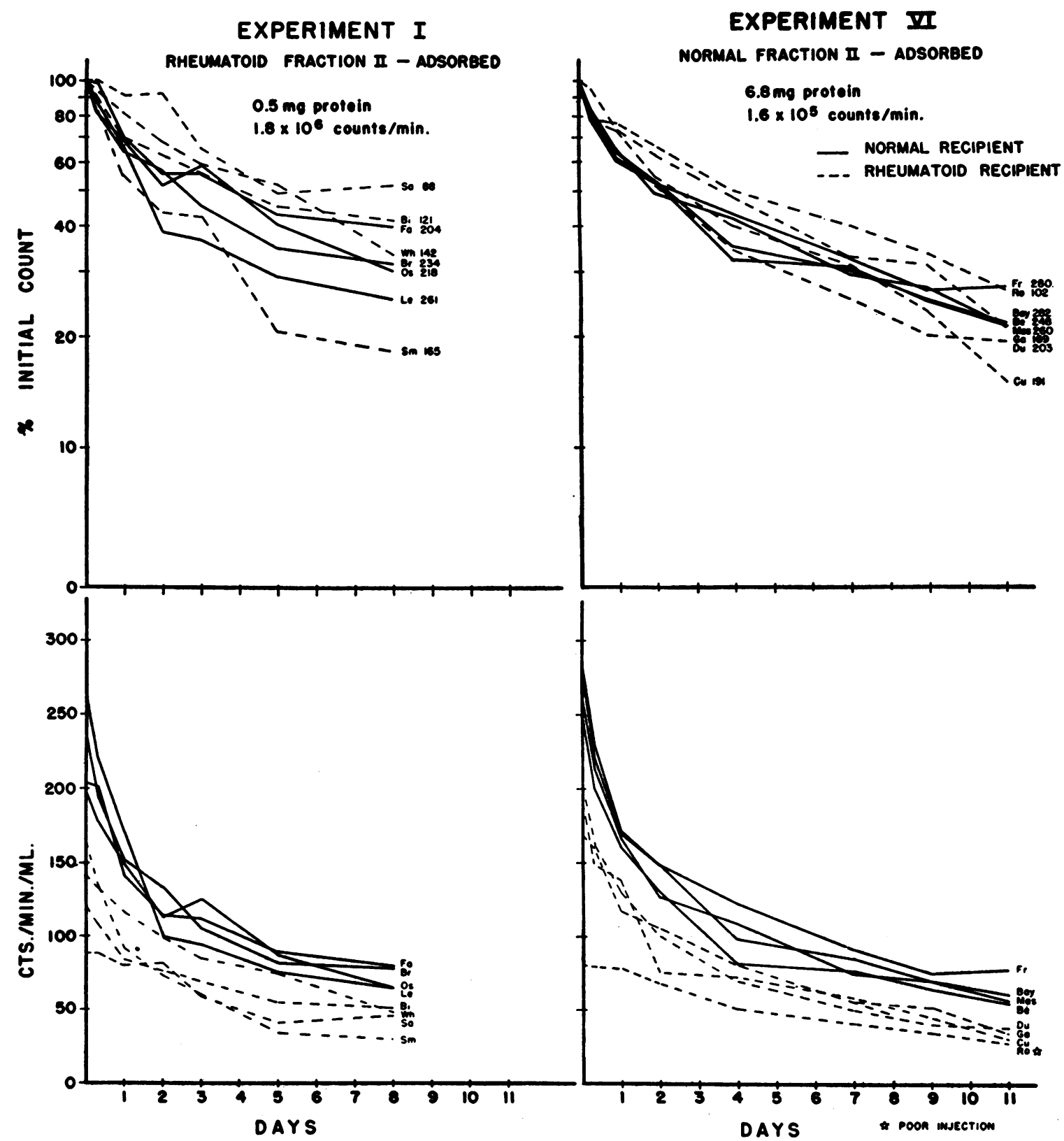

Figure 2.

In Experiments I and VI there was an immediate removal of significant amounts of radioactive material from the blood of rheumatoid individuals, after which the curves were almost identical. The upper curves are re-plotted below against counts per minute per milliliter better to illustrate the significance of the lack of overlap in the initial (30-minute) plasma samples. 

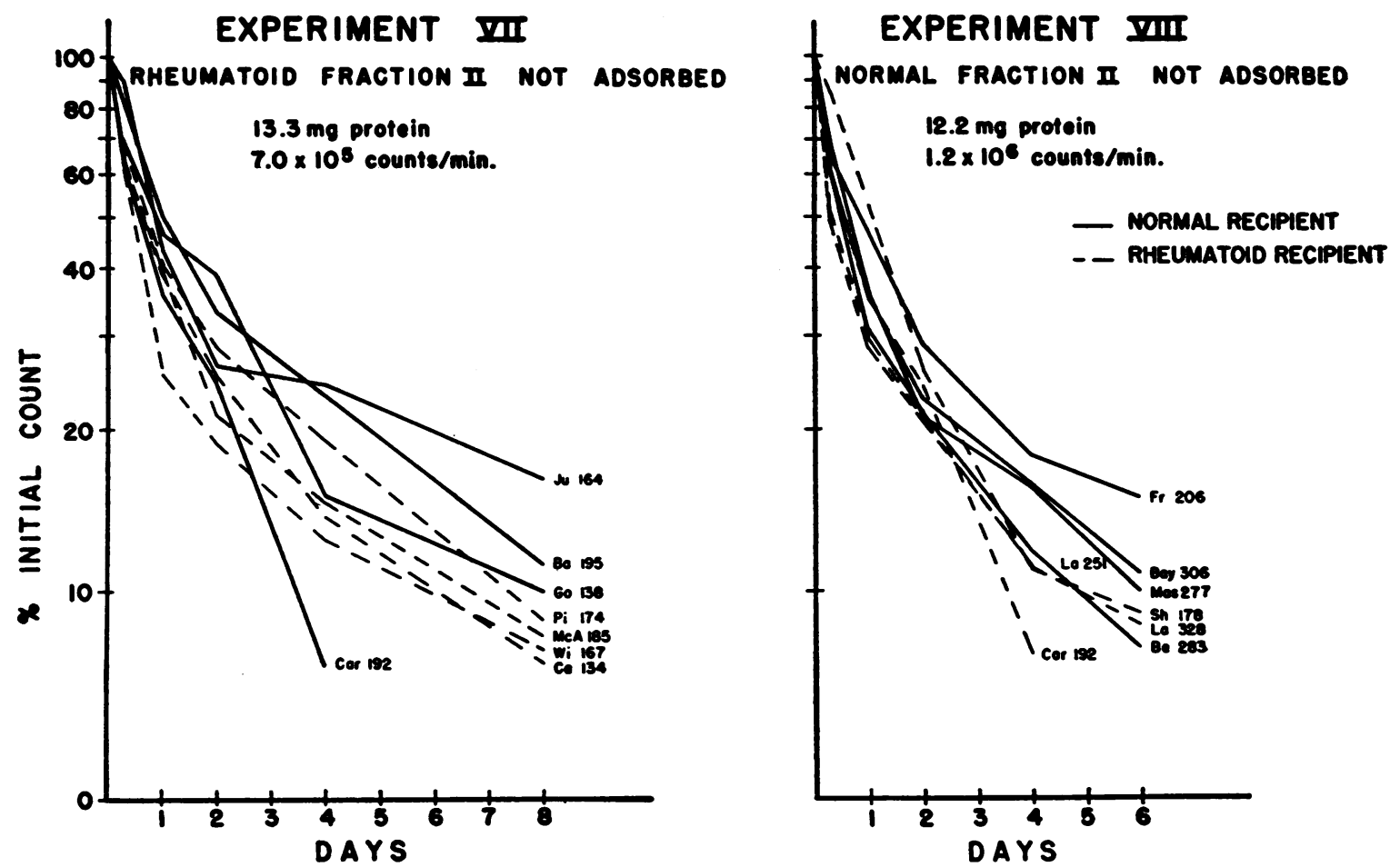

Fig. 3. Experiments VII aNd VIII, Illustrating the Rapid Loss of Radioactivity from Both Norkal and Rheumatom Persons, Presumably on the Basis of Degradation during Preparation of the Injected Material

was in those from the normal subjects, as though the rheumatoid group had almost immediately removed one-third to one-half of the injected material from the circulation, perhaps on the basis of phagocytosis of aggregated or precipitated material. The subsequent portions of the curves were not definitely different from each other. Values are plotted in the lower half of Figure 2 as absolute counts, better to illustrate these observations. In none of the other six experiments was this phenomenon seen.

The results in Experiments VII and VIII are presented in Figure 3. In each of these instances there was unusually rapid disappearance of radioactivity from the blood, not only of the patients but of the controls as well, suggesting that during the isolation and iodination procedures in these experiments there was serious degradation of the protein. Again, this phenomenon was more striking in rheumatoid subjects than in controls; a finding in keeping with the tendency noted earlier, in Experiments II-V.

To rule out the possible influence of the known isoagglutinogens as complicating factors in this study, half of the experiments were done with Fraction II pools previously adsorbed with type $A B, R h$ positive erythrocytes, and half were done

TABLE I

Partition of radioactioity between the plasma protein fractions after injection of labelled fraction II in experiment III

\begin{tabular}{lcccc}
\hline \hline Name & $\begin{array}{c}\text { Day after } \\
\text { injection }\end{array}$ & $\begin{array}{c}\text { Cts./min./mi. } \\
\text { unfractionated }\end{array}$ & $\begin{array}{c}\text { Cts./min./ml. } \\
\text { I \& II \& III }\end{array}$ & $\begin{array}{c}\text { Ct./min./ml. } \\
\text { IV \& V }\end{array}$ \\
\hline $\mathrm{Br}$ & 2 & $421(177)^{*}$ & 172 & 7.1 \\
& 7 & $176(106)$ & 109 & 3.0 \\
$\mathrm{Ra}$ & 2 & $503(211)$ & 202 & 5.2 \\
& 7 & $221(130)$ & 124 & 10.3 \\
$\mathrm{Le}$ & 2 & $512(215)$ & 185 & 8.9 \\
& 7 & $212(125)$ & 83 & 0.8 \\
Os & 2 & $469(197)$ & 232 & 11.8 \\
& 7 & $202(119)$ & 116 & 5.3 \\
$\mathrm{Bi}$ & 2 & $437(183)$ & 210 & 2.0 \\
& 7 & $173(102)$ & 81 & 7.2 \\
$\mathrm{Sa}$ & 2 & $411(172)$ & 172 & 3.0 \\
& 7 & $164(97)$ & 80 & 7.5 \\
$\mathrm{Sm}$ & 2 & $319(134)$ & 118 & 7.1 \\
& 7 & $110(65)$ & 57 & 6.3 \\
Wh & 2 & $513(215)$ & 184 & 4.0 \\
& 7 & $188(109)$ & 111 & 12.7 \\
\end{tabular}

* Figures in parentheses represent the corrections for the decay that occurred in the ten-day interval between the readings of the unfractionated and fractionated materials. These corrected values are to be compared with the readings obtained on the fractionated material. 
TABLE 11

The appearance of radioactioity in the urine

\begin{tabular}{|c|c|c|c|c|c|c|c|c|}
\hline \multirow[b]{2}{*}{ Exper. } & \multirow[b]{2}{*}{ Name } & \multirow{2}{*}{$\begin{array}{c}\text { (1) } \\
\text { Days } \\
\text { after } \\
\text { injection }\end{array}$} & (2) & $\begin{array}{c}(3) \\
\text { Urine }\end{array}$ & (4) & \multirow{2}{*}{$\begin{array}{l}\text { (5) } \\
\text { \% Inected } \\
\text { cts. lost } \\
\text { per day* }\end{array}$} & \multirow{2}{*}{$\begin{array}{c}\text { (6) } \\
\text { Total cts. } \\
\text { injected }\end{array}$} & \multirow{2}{*}{$\begin{array}{l}\text { (7) } \\
\text { Cts. calculated } \\
\text { from (5) and } \\
\text { (6) to appear } \\
\text { in urine }\end{array}$} \\
\hline & & & Cls./min./ml. & Vol. & Counts & & & \\
\hline II & $\begin{array}{l}\mathrm{Cr} \\
\text { No }\end{array}$ & $\begin{array}{l}2 \\
2\end{array}$ & $\begin{array}{l}126 \\
139\end{array}$ & $\begin{array}{r}1,000 \\
620\end{array}$ & $\begin{array}{r}126,000 \\
80,500\end{array}$ & $\begin{array}{l}14.5 \\
14.5\end{array}$ & $\begin{array}{l}2.65 \times 10^{6} \\
2.65 \times 10^{6}\end{array}$ & $\begin{array}{l}320,000 \\
320,000\end{array}$ \\
\hline IV & $\begin{array}{l}\mathrm{Ra} \\
\mathrm{St} \\
\mathrm{Bo} \\
\mathrm{Cr} \\
\mathrm{No}\end{array}$ & $\begin{array}{r}7 \\
14 \\
14 \\
15 \\
2 \\
3 \\
1 \\
1\end{array}$ & $\begin{array}{r}124 \\
60 \\
64 \\
92 \\
334 \\
330 \\
301 \\
315\end{array}$ & $\begin{array}{r}1,500 \\
1,340 \\
1,020 \\
600 \\
1,000 \\
700 \\
1,100 \\
400\end{array}$ & $\begin{array}{r}186,000 \\
82,400 \\
62,000 \\
55,000 \\
334,000 \\
231,000 \\
537,700 \\
126,000\end{array}$ & $\begin{array}{r}10.5 \\
10.5 \\
10.2 \\
8.7 \\
17.0 \\
17.0 \\
6.9 \\
6.9\end{array}$ & $\begin{array}{l}4.83 \times 10^{6} \\
4.83 \times 10^{6} \\
4.83 \times 10^{6} \\
4.83 \times 10^{6} \\
4.83 \times 10^{6} \\
4.83 \times 10^{6} \\
4.83 \times 10^{6} \\
4.83 \times 10^{6}\end{array}$ & $\begin{array}{l}260,000 \\
108,000 \\
110,000 \\
108,000 \\
680,000 \\
563,000 \\
334,000 \\
310,000\end{array}$ \\
\hline
\end{tabular}

* Calculated from the formula: $\%=\frac{0.693}{t / 2}$ (cf. [15]).

with unadsorbed pools. Those pools which were adsorbed are indicated in the figures. The lack of an effect from adsorption might be expected, since it is known that isoagglutinins constitute an

TABLE III

Results of scanning with beta gamma survey meter 24 hours after injection in experiment $V$

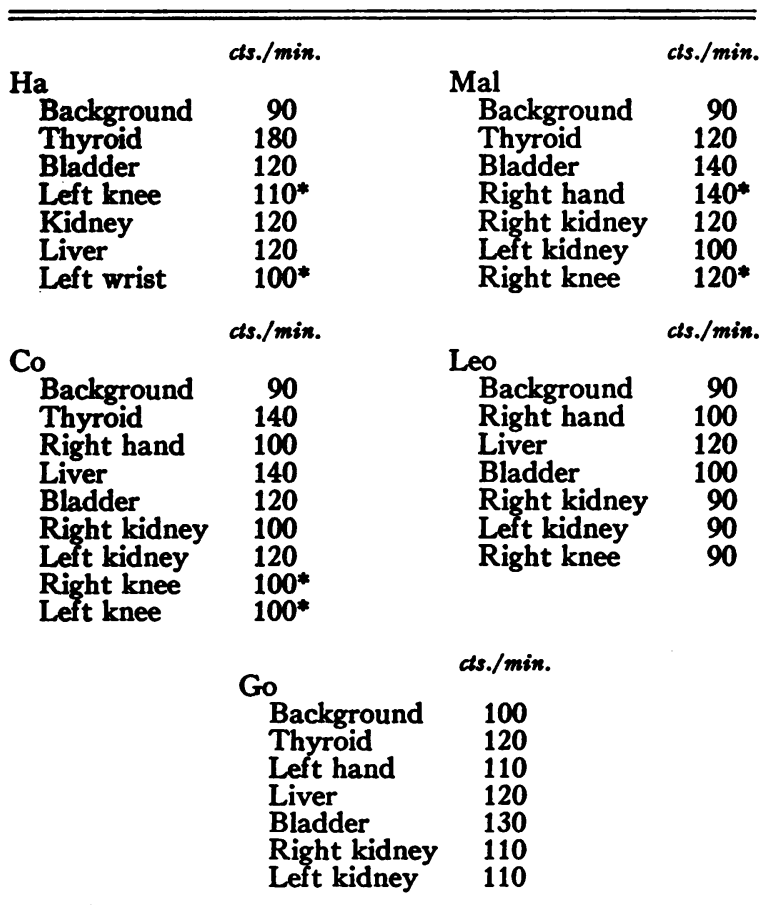

* Joints involved by rheumatoid arthritis.

The isoagglutinins are concentrated in Fraction III but by qualitative testing significant traces of these substances can also be found in Fraction II. extremely small part of the total plasma proteins (14).

In Table I are presented the data obtained from small scale fractionation of the plasmas of the subjects in Experiment III at two intervals following the injection of the labelled gamma globulin. It is evident that the injected material remained associated with Fraction I plus II plus III, no significant amount appearing in Fraction IV plus V. Similar results were obtained in several of the other experiments, the longest postinjection interval studied being two weeks.

The available data on urinary excretion of radioactivity are shown in Table II. In only one instance (Subject "No," first day of Experiment IV) was as much radioactivity found in the urine as might have been expected from a consideration of the plasma decay curves. This is illustrated by a comparison of columns No. 4 and No. 7, which indicates that approximately half the expected count was found in the urine. The amounts of iodine lost in the feces and perspiration were not measured but one would not have expected them to be high.

The surface of the body was scanned, as illustrated in Table III. There was no evidence for any specific localization of radioactivity over joints afflicted by arthritis.

In Figure 4 are shown the disappearance curves for commercial human albumin tagged with $I^{181}$ following intravenous administration in patients and controls. As with globulin, the patients re- 
moved the injected material from the circulation more rapidly than did the normals, and the differences in the values shown by these two groups on both the ninth and the tenth days are statistically significant ( $p=0.04$ and 0.01 , respectively). The appearance of the curves suggests that the mechanisms effecting the disappearance of albu-
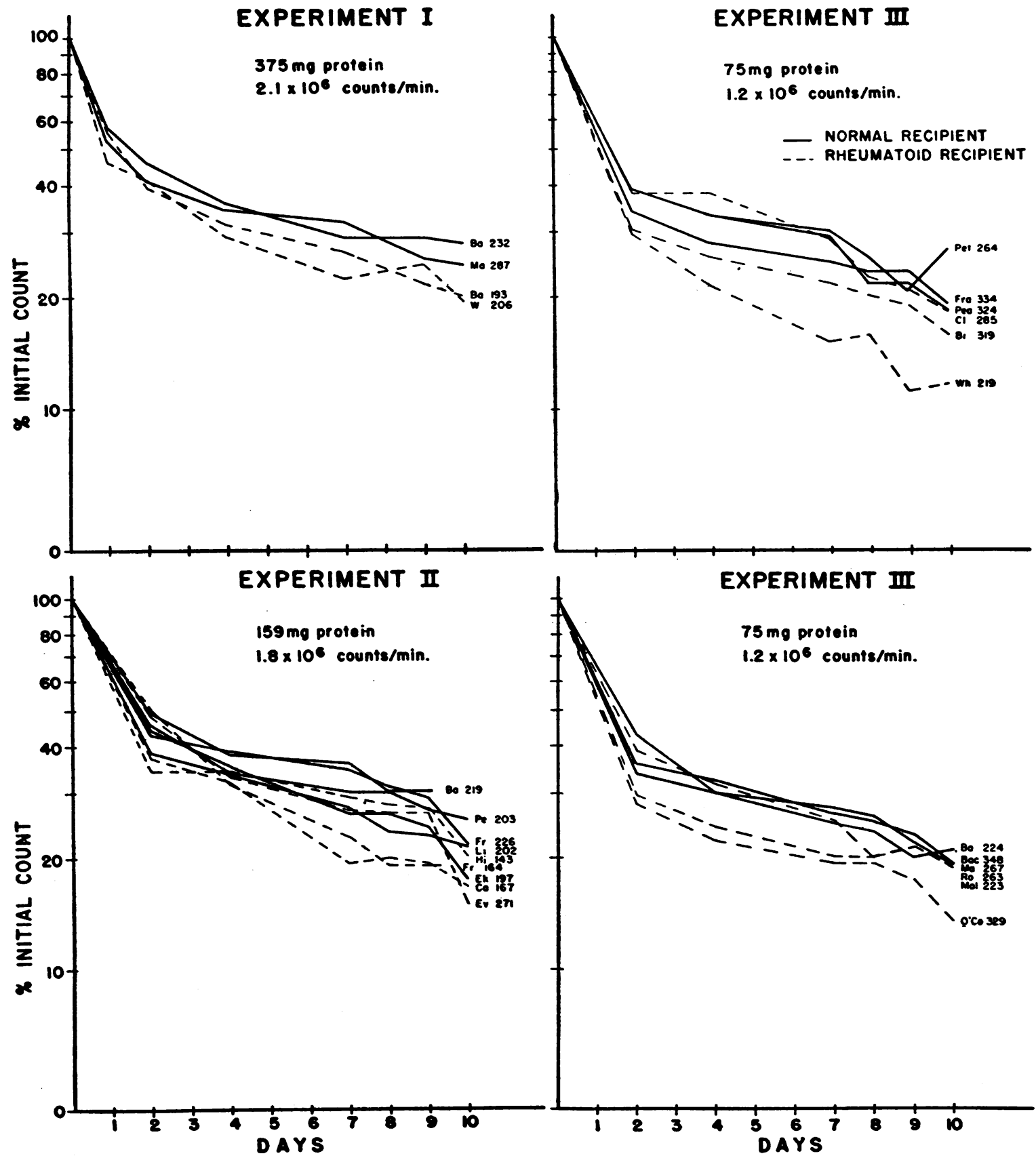

Fig. 4. Curves Illustrating the Disapprarance of Im-Tagge Commercial Human Albumm from the Circucation of Norual Individuals and of Patients with Rheumatom Adthrits

min are similar to those which were responsible for the disappearance of gamma globulin, and hence it is difficult to attribute any specificity to the more rapid removal of tagged globulin from the blood of the rheumatoid patients. The albumin disappearance curves for the normal subjects are comparable to those reported by Sterling (15).

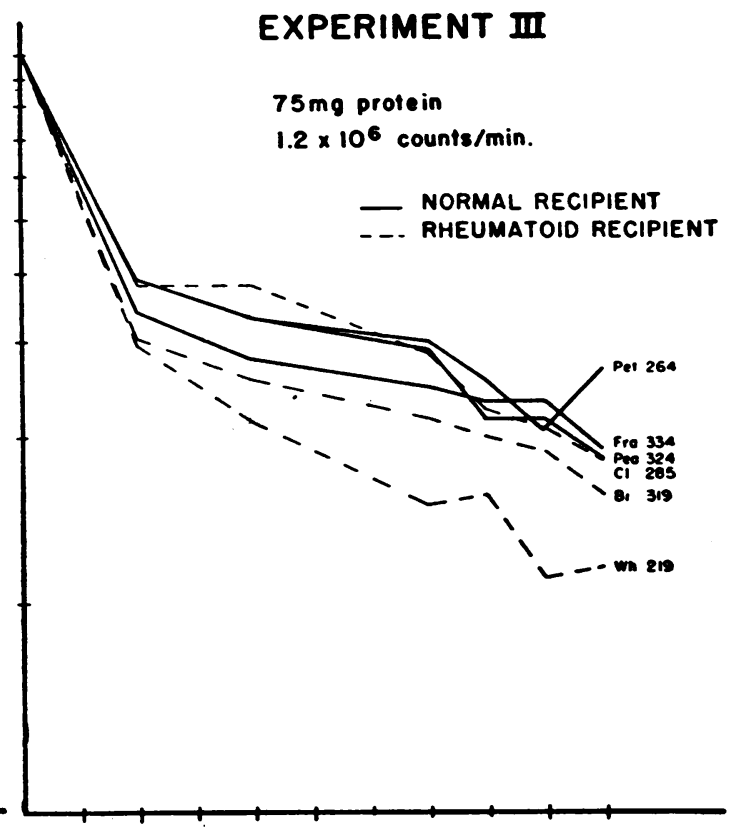

\section{EXPERIMENT III}

$75 \mathrm{mg}$ protein

$2 \times 10^{6}$ counts/min. 
TABLE IV

In vitro adsorption of fraction II by tissue

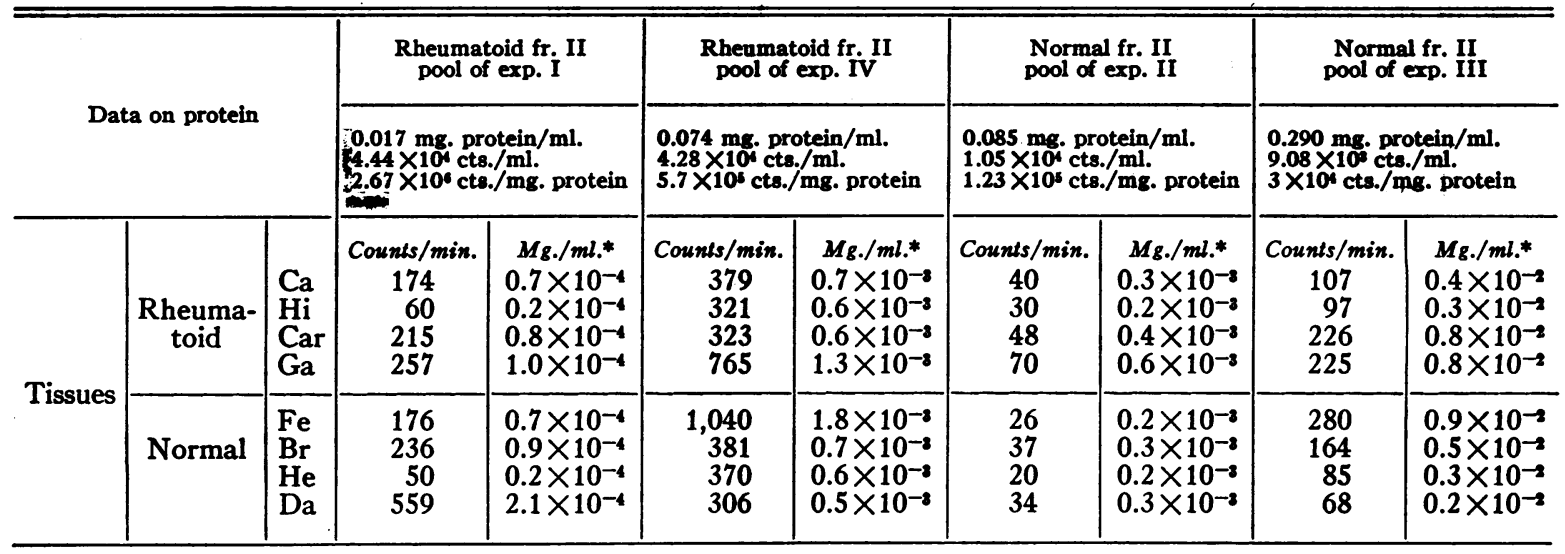

* Mg. adsorbed protein per ml. of 2 per cent tissue suspension.

\section{Part II. In vitro uptake of protein by tissue}

In the second approach to the problem of the possible relationship between plasma gamma globulin and tissue elements, aliquots of the pools of Fraction II used in Experiments I through IV were equilibrated against homogenized tissue stromata. The tissue was then washed free of unbound radioactivity and resuspended in saline. One ml. aliquots of these suspensions were counted for radioactivity. The results are given in Table IV. It is evident that there is no tendency for the rheumatoid tissues preferentially to take up a given gamma globulin preparation. There was definite adsorption of globulin by all the tissue preparations, both normal and rheumatoid, but the extent of this adsorption appeared to be proportional to the protein concentration of the pool in which the tissue was suspended. Thus the pools of Experiments I, II, and III were of regularly increasing protein concentration and the tissues exposed to them adsorbed, respectively, on the order of $10^{-4}, 10^{-3}$, and $10^{-2} \mathrm{mg}$. of protein. In the two experiments done at approximately the same protein concentration, i.e., those using the pools of Experiments II and IV, both the rheumatoid and normal tissues appeared to adsorb a slightly greater amount of the rheumatoid globulin. However, in view of the considerably greater magnitude of the differences noted to be due to concentration alone, these slight differences cannot be considered significant.
Part III. In vivo uptake of protein by tissue

The third approach to the problem of globulintissue relationship was an attempt to determine whether the tagged protein would localize on joint tissues in vivo. Three different types of protein were used: rheumatoid Fraction II, normal Fraction II, and normal Fraction V. These were prepared as in the other experiments and each type was given intravenously to a series of subjects with different types of joint disease on the day preceding an orthopedic operation. Radioactivity was measured in surgically removed specimens and compared to the radioactivity found in plasma taken at the time of operation. The data in Table $\mathrm{V}$ show the values obtained in this correlative study to be widely scattered with no apparent relationship to protein used or to disease. Normal Fraction II was not differentiated from rheumatoid Fraction II, and the tissues in non-rheumatoid inflammatory joint disease apparently contained as much radioactivity as did the rheumatoid tissues. After injection of tagged Fraction V comparable amounts of radioactivity were found in the tissues in one of three experiments. The most important factor determining the amount of radioactivity in the tissue seemed to be the tissue's physical characteristics; vascularity, edema, and exudation appeared to increase, and a high proportion of fat to decrease, these values.

Localization of radioactivity in histamine wheals. In several experiments tagged rheumatoid Fraction II was injected intravenously; fol- 
lowing this, histamine wheals were produced in the skin (by injection of $0.1 \mathrm{ml}$. of histamine phosphate 1:1000 intradermally) and the appearance of radioactivity in these wheals measured. In general the number of counts correlated fairly well with the size of the histamine wheal and flare. However, to a measurable extent, the amount of radioactivity over an area of skin was influenced by general vascular effects, such as those accompanying changes in skin temperature. There was on one occasion a marked difference in control counts at different times and this was considered to be due, at least in part, to such a factor, in that when the subject was warmer and more relaxed more radioactivity was recorded. Furthermore it was possible to reproduce such variations, though to a lesser degree, by exposing the subject first to $4^{\circ} \mathrm{C}$. and then to $37^{\circ} \mathrm{C}$.

\section{DISCUSSION}

This report describes efforts to find a relationship between plasma gamma globulin and joint tissue in rheumatoid arthritis. Recently advanced techniques of plasma fractionation and radio isotope tagging were employed. ${ }^{131}$-labeled Fraction II (gamma globulin) of both normal and rheumatoid origins was equilibrated in vitro and in vivo with normal and rheumatoid joint tissue and the uptake of radioactivity by the tissue measured. In addition, the disappearance of similarly tagged protein from the blood was followed in rheumatoid patients and controls.

Although none of the subjects and none of the tissues studied appeared to differentiate between normal and rheumatoid globulin, a review of the curves expressing the disappearance of the tagged proteins from the blood revealed two facts worthy of note. First, there was considerable variability in the different gamma globulin experiments, and second, the patient with rheumatoid arthritis generally removed the injected protein from the circulation more rapidly than did the normal subject.

It was felt that the variability in experimental results was most likely due to a combination of two factors: First, the heterologous nature of gamma globulin which has been demonstrated by

TABLE V

In vivo uptake of protein by tissue

\begin{tabular}{|c|c|c|c|c|c|c|}
\hline & $\begin{array}{c}\text { Patient-Joint operated- } \\
\text { Diagnosis-Tissue }\end{array}$ & $\begin{array}{l}\text { Total } \\
\text { tissue }\end{array}$ & $\begin{array}{c}\text { Total } \\
\text { tissue N }\end{array}$ & $\begin{array}{c}\text { Cts./min./10 mg. } \\
\text { tissue N }\end{array}$ & $\begin{array}{c}\text { Cts./min./ml. } \\
\text { Plasma }\end{array}$ & $\frac{\text { Tissue cts. }}{\text { Plasma cts. }}$ \\
\hline \multirow{2}{*}{$\begin{array}{l}\text { 1) } \\
\text { 2) }\end{array}$} & \multicolumn{6}{|c|}{$\begin{array}{c}\text { Cts./min. } \\
\text { Rheumatoid arthritis fraction II tagged with } I^{1 \mathrm{n}} \text { and injected intravenously }\end{array}$} \\
\hline & $\begin{array}{l}\text { Sc-knee-RA- } \\
\text { Synovial tissue } \\
\text { McL-knee-RA- }\end{array}$ & 12.4 & 5.75 & 21.6 & 504 & 0.042 \\
\hline 3) & Synovial tissue & 198 & 13.17 & 150 & 1,110 & .136 \\
\hline 4) & $\begin{array}{l}\text { Synovial tissue } \\
\text { Le-knee-Traumatic }\end{array}$ & 388 & 3.9 & 995 & 1,205 & .825 \\
\hline \multirow{2}{*}{ 5) } & $\begin{array}{l}\text { arthritis-Patellar fat pad } \\
\text { Synovial tissue }\end{array}$ & $\begin{array}{r}2 \\
13\end{array}$ & $\begin{array}{r}13.73 \\
1.58\end{array}$ & $\begin{array}{c}2 \\
82.3\end{array}$ & 970 & $\begin{array}{l}.001 \\
.085\end{array}$ \\
\hline & meniscus-Synovial tissue & 18 & 17.14 & 10.5 & 1,015 & .014 \\
\hline
\end{tabular}

Normal fraction II tagged with $I^{131}$ and injected intravenously

1) $\mathrm{Ha}-\mathrm{knee}-\mathrm{RA}-$

Synovial tissue

764

2) $\mathrm{Ne}-\mathrm{knee}$-Traumatic

arthritis-Synovial tissue

3) Ga-knee-Traumatic arthritis-Synovial tissue

1) $\mathrm{Fl}$ - knee- $\mathrm{Ra}-$ Synovial tissue

2) Gr-hip-deg. jt. dis.Muscle

Joint capsule

3) Gigamentum teres Synovial tissue

79
4.68

29.76

20.52

Normal fraction $V$ tagged with $\Gamma^{11}$ and injected intravenously

$\begin{array}{rcc}130 & 16.8 & 77 \\ 4 & 127.0 & .315 \\ 25 & 23.8 & 10.5 \\ 14 & 23.75 & 6.1 \\ 4 & 38.36 & 1\end{array}$

1.46
1,120

1,372

1,861

290

.266

497

.0006

.0212

.0122 
others on the basis of immunochemical (16) and solubility (17) criteria; and second, unrecognized variations in the procedures by which the proteins were prepared. It is possible that varying degrees of denaturation may have occurred which would make the injected material more or less liable to removal from the circulation by the processes available to the body for dealing with foreign proteins. ${ }^{8}$

The more rapid disappearance of injected protein from the circulations of the rheumatoid patients may have been due to one or more of several causes. It is possible that this was only a part of a general difference in protein metabolism such as that responsible for the negative nitrogen balance that is often found in this disease (18). The effect of the age of the individual on the half-life of gamma globulin as described by Dixon, Talmage, Maurer, and Deichmiller (19) was also considered since in the present study the patients were generally older than the controls; however, no correlation between the rates of disappearance and the subjects' ages could be detected. The mere existence of chronic disease may have affected the curves, and future studies on patients with other conditions may serve to shed some light on the specificity of this phenomenon. The possibility was considered that the low values in the rheumatoid patients could have been a distributional effect dependent upon a gradual equilibration of the injected material through abnormally large total body protein pools, the latter, perhaps, in part induced by a tendency for proteins to leak into areas of inflammation. This possibility could not be excluded, but to evoke it as an explanation would require the added hypothesis that in the present study the time needed for the proteins to reach this equilibrium was considerably longer

\footnotetext{
8 Since the preparation of this paper an article has appeared by Berson, S. A., Yalow, R. S., Schreiber, S. S., and Post, J., Tracer experiments with I-131-labeled human serum albumin: distribution and degradation studies. J. Clin. Invest., 1953, 32, 746. These authors call attention to the variability which may be found in presumably homogeneous proteins which are labeled when they are studied by measuring their disappearance from the blood stream after intravenous injection. They emphasize the importance of viewing with skepticism the concept that such disappearance rates accurately reflect the actual metabolism of the protein under investigation, as the material injected may have lost a significant portion of its original identity.
}

than the one to three-day period that has been described by others in similar studies (15). Finally, this observation can be interpreted as indicating that the patient with rheumatoid arthritis possesses immunological or other mechanisms whereby it is possible for him to remove aggregated or precipitated protein material from the blood stream more rapidly than is possible for the normal control.

\section{SUM MARY}

No evidence was obtained to support the concept of a specific relationship between joint tissue and plasma gamma globulin in rheumatoid arthritis. Neither normal nor rheumatoid subjects, nor their independently studied joint tissues in vitro or in vivo, differentiated between normal and rheumatoid I ${ }^{131}$-labeled Fraction II.

It was observed that the elimination of injected proteins from the circulation in rheumatoid patients was more rapid than in normal subjects.

The possible mechanisms responsible for this finding are discussed.

\section{REFERENCES}

1. Robinson, W. D., Duff, I. F., Block, W. D., and Foster, P. W., Electrophoretic pattern of plasma proteins in rheumatoid arthritis. Ann. Rheumat. Dis., 1950, 9, 383.

2. Dawson, M. H., Olmstead, M., and Boots, R. H., Agglutination reactions in rheumatoid arthritis. I. Agglutination reactions with streptococcus hemolyticus. J. Immunol., 1932, 23, 187.

3. Rose, H. M., Ragan, C., Pearce, E., and Lipman, M. O., Differential agglutination of normal and sensitized sheep erythrocytes by sera of patients with rheumatoid arthritis. Proc. Soc. Exper. Biol. \& Med., 1948, 68, 1.

4. Pike, R. M., Sulkin, S. E., and Coggeshall, H. C., Serological reactions in rheumatoid arthritis. I. Factors affecting the agglutination of sensitized sheep erythrocytes in rheumatoid-arthritis serum. J. Immunol., 1949, 63, 441.

5. Wallis, A. D., Rheumatoid arthritis. II. Non-specific serologic reactions. Am. J. M. Sc., 1946, 212, 716.

6. Lansbury, J., Crosby, W. R., and Bello, C. T., Precipitin reaction of serum from cases of rheumatoid arthritis with homologous connective tissue extracts. Am. J. M. Sc., 1950, 220, 414.

7. Lever, W. F., Gurd, F. R. N., Uroma, E., Brown, R. K., Barnes, B. A., Schmid, K., and Schultz, E. L., Chemical, clinical, and immunological studies on the products of human plasma fractionation. XL. Quantitative separation and determination of 
the protein component in small amounts of normal human plasma. J. Clin. Invest., 1951, 30, 99.

8. Cohn, E. J., Gurd, F. R. N., Surgenor, D. M., Barnes, B. A., Brown, R. K., Derouaux, G., Gillespie, J. M., Kahnt, F. W., Lever, W. F., Liu, C. H., Mittelman, D., Mouton, R. F., Schmid, K., and Uroma, E., A system for the separation of the components of human blood: Quantitative procedures for the separation of the protein components of human plasma. J. Am. Chem. Soc., 1950, 72, 465.

9. Latta, H., Experimental hypersensitivity in the rabbit: Blood and tissue concentrations of foreign proteins labeled with radioactive iodine and injected intravenously. J. Immunol., 1951, 66, 635.

10. Pressman, D., The zone of localization of antibodies. III. The specific localization of antibodies to rat kidney. Cancer, 1949, 2, 697.

11. Folin, O., and Ciocalteu, V., On tyrosine and tryptophane determinations in proteins. J. Biol. Chem., 1927, 73, 627.

12. Brand, E., Kassell, B., and Saidel, L. J., Chemical, clinical, and immunological studies on the products of human plasma fractionation. III. Amino acid composition of plasma proteins. J. Clin. Invest., 1944, 23, 437.

13. Pressman, D., and Keighley, G., The zone of activity of antibodies as determined by the use of radio- active tracers; The zone of activity of nephritoxic antikidney serum. J. Immunol., 1948, 59, 141.

14. Kabat, E. A., and Mayer, M. M., Experimental Immunochemistry. Springfield, Charles C Thomas, 1948.

15. Sterling, K., The turnover rate of serum albumin in man as measured by Im-tagged albumin. J. Clin. Invest., 1951, 30, 1228.

16. Kabat, E. A., and Murray, J. P., A comparison of human $\gamma$-globulins in the reactivity with rabbit anti- $\gamma$-globulin by the quantitative precipitin method. J. Biol. Chem., 1950, 182, 251.

17. Cohn, E. J., Strong, L. E., Hughes, W. L., Jr., Mulford, D. J., Ashworth, J. N., Melin, M., and Taylor, H. L., Preparation and properties of serum and plasma proteins. IV. A system for the separation into fractions of the protein and lipoprotein components of biological tissues and fluids. J. Am. Chem. Soc., 1946, 68, 459.

18. Ropes, M. W., and Clark, W. S., Personal communication.

19. Dixon, F. J., Talmage, D. W., Maurer, P. H., and Deichmiller, M., The half-life of homologous gamma globulin (antibody) in several species. J. Exper. Med., 1952, 96, 313. 